\title{
MIMR TRAINEE TEACHERS POST-TRAINING QUALITATIVE ASSESSMENT ON SEXUAL REPRODUCTIVE HEALTH FOR SPECIAL CHILDREN
}

\author{
Nur Ezdiani Mohamed ${ }^{1,2}$, Siti Diyana Ibrahim ${ }^{1,2}$, Abdul Rahman Ramdzan ${ }^{1,3}$, Nur Ashiqin \\ Abdul Rahman ${ }^{1,2}$, Sutan Rosnah ${ }^{1 *}$, Alijah Ujang ${ }^{4}$ \\ 'Department of Community Health, Universiti Kebangsaan Malaysia Medical Centre, Kuala Lumpur, \\ Malaysia \\ ${ }^{2}$ Ministry of Health, Malaysia \\ ${ }^{3}$ Department of Community and Family Medicine, University Malaysia Sabah, Malaysia \\ ${ }^{4}$ Special Education Department, Institute of Teacher Education Ilmu Khas Campus, Cheras Kuala \\ Lumpur, Malaysia \\ *Corresponding Author's email: rosnah.sutan@ppukm.ukm.edu.my
}

\begin{abstract}
Introduction Providing training on areas of known social cultural limitation such as sexual and reproductive health (SRH) is challenging and many end up with improper training. Present study aims to explore facilitators' skills and exploring feedback on the SRH program implementation. A training program was conducted based on existing module developed by Ministry of Health Malaysia. The focus of the training is on imparting essential sexual reproductive health knowledge for the teachers and instilling confidence in educating it on children and adolescents particularly those with disabilities. Methods The respondents were enrolled from a training centre for teachers trained for special needs children. The fascilitators of the program were the public health doctors in training. A case studies design was used to explore the themes. Nine focus group discussions comprising 15 participants each were conducted on teachers who had participated in the training. A semi-guided questionnaire was used to guide the discussion. Discussions were audio and video recorded with permission then transcribed verbatim. Transcriptions were analysed using thematic analysis to capture similarities and differences in views expressed by the participants. Results Eight themes were derived. Three related to the facilitators which were personality and characteristics, knowledge and skills. Five were related to the programme implementation - time, input, output, outcome and venue.Conclusion Generally, the programme received positive remarks. Programme input needs further improvement. Based on the participants' feedback, the programme managed to achieve its objectives. Facilitators were able to facilitate the training satisfactorily.
\end{abstract}

Keywords: Sexual and reproductive health, Training, Evaluation, Teacher, Evaluation, Malaysia, qualitative study

\section{INTRODUCTION}

Adolescence is a transitional period of a boy or a girl from childhood to adulthood.(WHO, 2018) Even though adolescent had been traditionally defined by age between 10 and 19 year old, there are many other changes they need to go through. During this period, adolescents will experience change from dependency on their parents to independence, being more autonomous and gradually maturing. A transition not only affects their psychological and social sphere, but, these are also linked to the changes in physical, neurodevelopmental and physiological aspects. The most significant change during adolescence might be related to sexual reproductive health (SRH) itself. It involved a visible change in the physical especially reproductive aspects of the body; state as well as subtle change or may be turmoil in the mental and social wellbeing of an adolescent. These changes have always been a sensitive topic to be discussed and taught among the society members.

Similarly, special children and adolescents or children and adolescents with disabilities to undergone these 
changes. Despite the assumption of them being asexual (Greydanus \& Omar, 2008; Zhagan, 2012), they are more vulnerable to abuse, sexual dysfunctions as complications of their disorder and experience psychological effects of their condition.(Greydanus \& Omar, 2008) People with disabilities are living longer now. Some choose to marry and build a family, rebutting the myth of their asexuality as what usually perceived by the society (Hunt et al., 2017).

The International Conference on Population and Development in Cairo in 1994 had laid a foundation in advocating for systematic program in educating SRH for adolescents (Chandra-Mouli et al., 2015). Malaysia, being part of the convention, adopted the definition and introduced programs in creating awareness, influencing attitude and changing behavior towards better sexual health in collaboration with the Ministry of Education, Ministry of Health and other relevant agencies such as National Population and Family Development Board (LPPKN). SRH education in Malaysia has been introduced as early as seven years old as part of the Pendidikan Jasmani Dan Kesihatan subject during the primary school years since 1994 (Narimah et al., 2007). Teachers become the important educating tool throughout the schooling phase. Additionally, Ministry of Health Malaysia together with persons and professionals from Hospital, Universities, NGOs and private sectors had produced Training Module "Live Life, Stay Safe" in 2009, to be used by teachers as a guide in teaching SRH for children and adolescents with disabilities.(MOH, 2009)

Teachers have to realize their important role in educating SRH. Zhagan (2012) reported Down Syndrome girls who were interviewed in the study regarded teachers as the second source of information for reproductive health after their parents. However, in another study among secondary school teachers in Kuala Lumpur and Klang Valley area, Kamrani and Yahya (2016) found out that teachers faced barriers themed as teacher's weakness, parental constraints and school constraints in teaching sexual health education for the students. Teacher weakness relates to inappropriate teaching strategy and inadequate teaching strategy.(Kamrani \& Yahya, 2016). Previously, a review in 2005 too mentioned similar barriers like teacher slackness in dealing with a sensitive topic and shying away from teaching it.(Narimah et al., 2007). If they faced barriers in teaching normal children and adolescents, it must be more challenging to educate SRH to adolescents with disabilities or special needs.

Widespread of news on an autistic youth masturbating on MRT while looking at a girl, in Singapore, (Chin, 2018) and an arrest of an autistic youth for molesting a 24 year old female in Subang Jaya, Malaysia; five days apart,(Mokhtar, 2018; Tang, 2018) were evidence of inadequate knowledge transfer and guidance for them. Children and adolescents with disabilities need to be educated properly on SRH. Thus, a training module was developed by a group of postgraduate community health students to impart essential SRH knowledge and instill confidence among teachers in educating and recognizing $\mathrm{SRH}$ issues among children and adolescents, particularly those with disabilities. The training of trainers (TOT) session was carried out in a nearby teachers' training institute for students with special needs in Cheras, Kuala Lumpur. This is followed by a qualitative assessment aimed to evaluate the future Public Health Physician facilitation skills on SRH based on the developed module as well as exploring feedback from the teachers on the program implementation.

\section{METHODOLOGY}

\section{Study setting}

This evaluation is qualitative in nature. It was part of an assessment post training done by 19 postgraduate community health students from National University of Malaysia (UKM). Focus group discussions (FGDs) were conducted among 98 Special Education trainee teachers which will be referred to as participants from now on. This method was chosen as it was the most suitable and feasible technique, considering the highly sensitive research question and research context (Green $\&$ Thorogood, 2009). It allowed obtaining rich data through exploration of the focused-topic - postgraduate students' facilitation skills in training SRH and program implementation.

The FGDs were done at the Cheras Campus for Special Education Teacher Institute or known as IPG KIK located in the capital city of Malaysia, Kuala Lumpur after the training completion. This institute was opened since 1962; offering Special Education courses for teachers to teach children with learning problems, visual problems, hearing problems, and special recovery. The institute also provides regular courses 
such as Malay Language Studies, English Studies, Music Studies, Physical Education and Health and Visual Art Education. Trainees are enrolled from all over Malaysia.

\section{Data collection and ethical consideration}

The FGDs participants were Special Education trainee teachers in Semester 2 until 8. 141 of them were divided into nine training groups comprising between 7 and 15 participants each. Those who were involved in the training from $830 \mathrm{am}$ to $430 \mathrm{pm}$ were invited to remain in the FGDs session, which were made up to a maximum of one and a half hour. 98 participants participated. All of them who participated in the training program were eligible to be recruited. Participants who came late and/or not involved in the training program were excluded as they will not be able to give valid feedback based on the objectives of the assessment.

All participants provided written consent prior to the discussions following briefing on the FGDs. Each group was facilitated by a moderator assisted by a note taker. Both were the same facilitators leading the training group. Facilitators undergone a training session to get them familiarise with the guide as well as for standardisation.

All discussions were either audio or video-recorded or both with the participants' consent. Notes from the discussions were kept by the note taker. The same note taker transcribed the recordings verbatim. A semistructured guide was developed in the national language (Malay). Forward translation of both these questions and verbatim used in this paper was done by two experts in both English and Malay language. They are supplemented as appendices.

\section{Data analysis}

The principal method for data analysis was a largely descriptive qualitative thematic analysis. Qualitative description is proposed by Sandelowski $(2000,2010)$ as a valid pragmatic analysis approach in qualitative health research where "straight descriptions of phenomena are desired." The interviews were transcribed by the note taker, then repeatedly read by the first reviewer (moderator for each training group) to gain familiarity with the data. Notes taken during the interview were used in the transcription process. This is to allow for comments to be included in body language and facial expressions during the interview where relevant. The transcripts were coded inductively and categories indexed by the moderator. Note taker for each training group acted as a second reviewer to maximize reliability of the data generated from the coding.

Both first and second reviewer were experienced analysts. Codes created by the first reviewer were reviewed for relevance and completeness and the final code list reflects the researchers' consensus. The most relevant categories were then synthesised into emerging themes through consensus among the team members consisted of the first and second reviewers for each FGD group. For quality control, an initial code list was created based on literature and then similar codes were combined to form a more concise code list. Preliminary results were presented to relevant peer in research to scrutinize the data and interpretations by the group.(Green \& Thorogood, 2009) Verbatim in results were presented in the original language to preserve the authenticity. However, as mentioned earlier, these are supplemented as appendices.

\section{RESULTS}

There were 98 students involved as participants. This was about $70 \%$ of the total students joining the training. Table 1 shows the overview of their sociodemography. The responses can be broadly categorised into Program and Facilitator which correlate with the objectives of the qualitative assessment. Thematic analysis revealed five and three themes under the Program and Facilitator domain respectively. These are the categories generated for both themes (Figure 1). In general, positive feedbacks were echoed for both themes, however, a few aspects of Program need improvement. The teachers were happy to be part of the training, receiving information and technique in educating students with disabilities on the sensitive topic.

\section{Theme 1: Personality \& characteristics}

For them, the facilitators had been able to deliver the content truthfully with professionally. Being in similar age group, friendly, nice and attentive helps the coaching went smoothly. Facilitators were very comfortable, confident, helpful, open-minded, candid, responsible and charismatic in delivering the topic as well as responding to questions and answers. Even some of the questions were not included in the scope of 
the training.

\author{
“...kami tanya soalan luar skop tapi fasi still bagi \\ jawapan kat kami.
}

(we asked questions out of the scope yet faci still giving us answers)

\section{(Participant No 1, FGD Group 10)}

As facilitators were paired to handle each group for the training, some of the duo was seen as complementing each other as one was serious and the other was a bit laid back in facilitating. There was also feedback saying that one partner was more dominant than the counterpart. Facilitators had good appearance and credible.

\section{Theme 2: Knowledge}

Facilitators were adept. Input given were perceived as sufficient and more in-depth. However, facilitators were also suggested to know more tactful approach in teaching or suggesting to teachers. The approach used in the training with teaching aids was a bit explicit that straightway introduce the topic to students. For example, learning on the anatomy or body parts might trigger some student with disabilities to explore on friend.

Mungkin bagi saya, doktor pun kene tahu jugak bende tu. Lagilah budak ni dia amik direct je. Jadi apa yg dia nampak itu dia anggap dah betul. Jadi sebab tulah kene berhati-hati nak ajar tentang seksual. Macam kita nak ajar sentuhan selamat, tak selamat, kita tak tahu dlm otak dia, tau. Jadi dia nak test dengan kawan-kawan dia. Dia rasa bende tu lawak.

(Maybe for me, the doctor needs to know it [tactful approach] too. Even more with this kid, they take (everything) directly. So what he/she sees, he assumes that it is allowed. So need to be careful in teaching about sexuality (health). Just like teaching (them) on the safe touch and unsafe touch, we wouldn't know what's in his/her mind. So, he/she might want to test it with his/her friend. He/she thought it was laughable)

(Participant No 1, FGD Group 9)

\section{Theme 3: Skill}

Skill generated categories related to communication, rapport building and develop synergy. Communication involved receiving and delivering the input of the training. In term of delivery, some said there were facilitators with low voice tone and being too complex in explaining. However, most commented that speed of the speech was just nice with open and clear communication as well as good interaction and presentation. Facilitators were also delivering in relax, straightforward and casual mode. They were short and sweet and being a good listener.

Rapport building looked at the ability of facilitators in building connection or relationship with the participants. They were indeed able to draw more participants and understands what they want. Participants were comfortable to co-operate in the training session. In developing synergy, facilitator's involvement made the participants easy to focus. They provided proper guidance to gear the discussion towards the shared interests and goals.

\section{Theme 4: Time}

There were contrasting views on the timing of the session. Some perceived it was appropriate, but more voiced up for adjustment either to allow more participation as it clashes with other ongoing program, to lengthen and run the program only in the morning or to lengthen and add on some external activity.

“... tiga hari dua malam tu mungkin boleh, tapi kita include kan benda tu dengan aktiviti luar..."

(three days two nights are possible, but we include external activities with it [the programme])

\section{(Participants No 6, FGD Group 2)}

Punctuality were the main issue raised in term of time management. Even though the activities were running sequentially, it was rushed and done not within the stipulated time in the tentative.

\section{Theme 5: Input}

This theme relates to program content, its relevance in term of applicability of the program to the targeted audience, teaching aid used in the training and outsider involvement. Majority perceived that the information conveyed in the training were sufficient, dense, precise and suitable for children with disabilities. Positive views were given on the practical session where the hands-on activities made it easier to learn and comprehend the subject matter. In improving the 
content, some participants emphasised on revealing data to show the magnitude of the problem.

Some recommendations were also given for facilitators to incorporate a better approach in teaching children with disabilities as well as using role play to enrich experience in handling 'real' situation at school. There were mixed opinions on the relevance of the content for children with disabilities. Some thought it was important, good to be made as an early exposure and it was relevant. But, some were unsure of the content suitability for child with disabilities and what will the understanding of the students be if the module is applied.

The majority agreed that the learning materials were easy to be understood and implemented, attractive and comprehensive in achieving the programme's objective. But, there were also those who suggested alternative teaching technique and perceived that the materials were insufficient. Some participants were also suggesting involvement of the children with disabilities to enhance the program input.

"Kalau ada kanak-kanak tu kita libatkan, aplikasikan sendiri daripada [kepada] kanak-kanak berkeperluan khas tu. Maknanya kita boleh nampak, keberkesanan yang tadi kita belajar cara mengajar kanak-kanak tu, berkesan ke tak dengan cara tu."

(If we involved the children, applied it ourselves [onto] the children with soecial needs. Means we can see, the effectiveness of what [the lesson] we learned on method to teach the children, effective or not with the method)

(P11, FGD 2 \& 7)

\section{Theme 6: Output}

Almost all agreed that objective of the program was achieved. It was appropriate, interesting, done with suitable activity, increasing as well as strengthening their basic knowledge. For them it was a successful training. They were happy and satisfied. The topic was focused, easy to be applied, had increased their awareness as well as stressing the importance of sexuality education to students. Some even reported gaining new knowledge from the training. These include knowledge on disease management, new terminology, ideas on teaching aids and making a collaborative effort.

\section{Theme 7: Outcome}

For the participants, the program had managed to give some impact to their teaching technique. They felt inspired by the possible activities to be done and that their skills were improved. They too felt confident and not shy to teach or handle sexual reproductive health issues in future.

\section{Theme 8: Venue}

All echoed negative remarks on the venue.

Table 1 Overview of sociodemography of the participants

\begin{tabular}{|l|l|c|}
\hline No & Sociodemographics characteristics & $\%(\mathrm{~N}=98)$ \\
\hline \multirow{4}{*}{1.} & Age & \\
\cline { 2 - 3 } & $<25$ & 97 \\
\cline { 2 - 3 } & $\geq 25$ & 1 \\
\hline \multirow{4}{*}{2.} & Teaching experience (attachment in school) & \\
\cline { 2 - 3 } & Yes & 50 \\
\cline { 2 - 3 } & No & 48 \\
\hline \multirow{4}{*}{3.} & Hometown & 15 \\
\cline { 2 - 3 } & North Malaysia (Kedah, Penang, Perlis) & 29 \\
\cline { 2 - 3 } & West Malaysia (Perak, Negeri Sembilan, & \\
\cline { 2 - 3 } & Selangor, Kuala Lumpur) & 35 \\
\cline { 2 - 3 } & East Malaysia (Terengganu, Kelantan) & 7 \\
\cline { 2 - 3 } & South Malaysia (Johor, Melaka) & 12 \\
\cline { 2 - 3 } & Sabah and Sarawak & \\
\hline
\end{tabular}

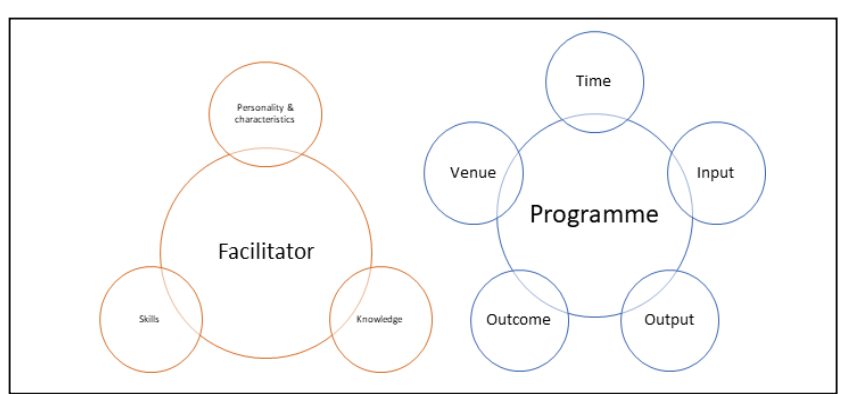

Figure 1: Objectives of the assessment relationship with themes identified in the assessment

\section{DISCUSSION}

In this study, training of SRH for children with disabilities helped the trainee teachers to gain their knowledge and increase their ability and skill to deliver 
the content to another friend and children with disabilities. The teachers' feedbacks were similar to another study in Bangladesh. The teachers in that study perceived benefit of the prepared lesson and reduced their misconception after joining the training session (Sarma, Islam, \& Gazi, 2013). A sensitive sensitive and quite a technical topic such as SRH is best to be taught for at least six days, especially for those without any experience learning it.((DSW), 2006). The training in Cheras was done only for one day.

Apart from that, a proper and adequate material for teaching is also one of the indicators for good teaching technique for similar programs (Ahmed et al., 2006). This aspect received generally good comments from the participants, though there were aspects related to content and suggestion for additional approaches like role play being echoed.

A successful training program happened when there is a competent facilitator. There are five domains in facilitator that was perceived to be able to give impact to the trainee. They are skilled and knowledge, selfawareness, social awareness, self-management and relationship management (National College for Teaching and Leadership, 2012). Skill and knowledge came out majorly positive in this evaluation. Relationship management is similar in personality and character theme in this analysis, which relates to their behavior and feeling such as friendly, true and comfortable in teaching approach while keeping in tune with the needs of their participants.

Proper facilitator training using a good method and aproach will increase transfer of knowledge between trainers and tranee. It will make the the programme more comprehensive (Denford, Abraham, Campbell, \& Busse, 2017). The result of the evaluation in term of programme and facilitator, showed a promising ability of the facilitator and usability of the programme.

\section{CONCLUSION, LIMITATION, REFLECTION, RECOMMENDATION}

The training achieved its objective. Facilitators were given mostly positive feedbacks on their facilitation skills. Participants were also generally satisfied with the program, but many improvements can be made in term of the input. The evaluation was done directly following the training by the same facilitators. This might influence the perticipants judgement. Furthermore, this result can only be applied to this qualitative evaluation. It can further be strengthened by comparing or cross validating it with a quantitative assessment on the participants. Good scoring achivement could indirectly indicate that the training was actually beneficial for them. Due to its nature as a case study, this study has given an understanding of how facilitation skills can be improved and effective in the future. Further evaluation on the impact of the programme to see whether teachers are able to impart the learned knowledge to their students will strengthen this evaluation.

\section{ACKNOWLEDGEMENTS}

We would like to express gratitude to our colleagues in Cohort 9 DrPH UKM who had helped us in data collection and analysis. They are (in alphabetical order) Ammar Amsyar AH, Azman A, Aznida MZ, Fadzrul Hafiz J, Khalid M, Mohd Fadhli MF, Mohd Shafik AM, Muhammad Aklil AR, Mohd Faizal M, Muhammad Haneef A, Nur Adibah MS, Raudah AR, Renuga Devi K, Wan Rosmawati WI, Zuraidah Z,

\section{CONFLICT OF INTERESTS}

No conflict of interest to be declared.

\section{REFERENCES}

Ahmed, N., Flisher, A. J., Mathews, C., Jansen, S., Mukoma, W., \& Schaalma, H. (2006). Process evaluation of the teacher training for an AIDS prevention programme. Health education research, Vol21(5), pp-621-632.

Chandra-Mouli, V., Svanemyr, J., Amin, A., Fogstad, H., Say, L., Girard, F., \& Temmerman, M. (2015). Twenty Years After International Conference on Population and Development: Where Are We With Adolescent Sexual and Reproductive Health and Rights? Journal of Adolescent Health, Vol56(1), pp-1-6.

Chin, N. C. (2018, 22 September 2018). 'Viral' video of autistic man masturbating on MRT train sparks calls for greater empathy. Today. Retrieved from: https://www.todayonline.com/singapore/viral- 
video-autistic-man-masturbating-mrt-train-sparkscalls-greater-empathy

Denford, S., Abraham, C., Campbell, R., \& Busse, H. (2017). A comprehensive review of reviews of school-based interventions to improve sexual-health. Health psychology review, Vol 11(1), pp-33-52

(DSW), G. F. f. W. P. (2006). Sexual and Reproductive Health Training Manual for Young People Retrieved from: https:// www. k4health.org/ sites/default/files/ DSW_training\%20manual_Eng_0.pdf

Green, J., \& Thorogood, N. (2009). Qualitative methods for health research ( $6^{\text {th }}$ ed.): SAGE.

Greydanus, D. E., \& Omar, H. A. (2008). Sexuality Issues and Gynecologic Care of Adolescents with Developmental Disabilities. Pediatr Clin N Am, Vol 55(6), pp-1315-1335.

Hunt, X., Carew, M. T., Braathen, S. H., Swartz, L., Chiwaula, M., \& Rohleder, P. (2017). The sexual and reproductive rights and benefit derived from sexual and reproductive health services of people with physical disabilities in South Africa: beliefs of non-disabled people. Reproductive Health Matters, Vol 25(50), PP 66-79.

Kamrani, M. A., \& Yahya, S. S. (2016). Bringing X, Y, Z Generations Together to Facilitate School-Based Sexual and Reproductive Health Education. Global Journal of Health Science, Vol 8(9), pp-132-138.

MOH. (2009). Training Module, Live Life, Stay Safe Kuala Lumpur: Proprint Enterprise

Mokhtar, N. A. (2018, 16 September 2018). Arrest of autistic man in molest case conducted in accordance with SOP, says police chief. New Straits Times. Retrieved from: https://www.nst.com.my/news/ nation/2018/09/411968/arrest-autistic-man-molestcase-conducted-accordance-sop-says-police

Narimah, A., Ang, E. S., Sarinah, L. W. Y., Mary, H. S. L., Mymoon, A., \& Nik Rubiah, N. A. R. (2007). Sexual and reproductive health of adolescents and youths in Malaysia a review of literature and projects 2005. Retrieved from : http://www.wpro. who.int/publications/docs/ASRHmalaysia.pdf

National College for Teaching and Leadership. (2012). The facilitation competency framework. Retrieved from: https://www.nationalcollege. org.uk/transfer/open/facilitation/fac-s4/fac-s4t2.html

Sarma, H., Islam, M. A. \& Gazi, R. (2013). Impact of training of teachers on their ability, skills, and confidence to teach HIV/AIDS in classroom: a qualitative assessment. BMC public health, vol 13(1), pp 990.

Tang, A. (2018, 17 September 2018). 'You're in a Gerak Khas movie', mother told adult autistic son when he was arrested. The Star Online. Retrieved from Read more at Retrieved from: https:// www.thestar. com. my/news/nation/2018/09/17/youre-in-a-gerakkhas-movie-mother-told-adult-autistic-son-whenhe-was-arrested/\#0ErpmrGP6rEJ5zZO.99

WHO. (2018). Adolescent development.Maternal, newborn, child and adolescent health. Retrieved from: http://www.who.int/ maternal child adolescent/topics/adolescence/development/en/

Zhagan, M. (2012). Understanding of Parents and Adults on the Down syndrome Female Sexual Reproductive Health. The Malaysian Online Journal of Educational Science, vol 1(4) 